ПОЗАНАВЧАЛЬНА ДІЯЛЬНІСТЬ СТУДЕНТСЬКОЇ МОЛОДІ ЯК УМОВА
ФОРМУВАННЯ ФІЗКУЛЬТУРНО-ОЗДОРОВЧОЇ КОМПЕТЕНТНОСТІ

\title{
EXTRACURRICULAR ACTIVITIES OF STUDENT YOUTH AS A CONDITION OF FITNESS AND HEALTH COMPETENCES FORMATION
}

Стаття присвячена одній $з$ актуальних проблем підготовки майбутніх висококваліфрікованих фрахівців технічних галузей виробництва. Зокрема, формуванню у студентів вищих технічних закладів освіти не тільки професійної компетентності, а і фрізкультурно-оздоровчої компетент ності. У вищому технічному закладі освіти здоров'язбереження не може бути основною метою освіти, але має бути головною умовою освітнього процесу в університеті, пов'язаного зі здобутками особистих досягнень освіти студентів. Мета проведеного нами дослідження - зробити аналіз освітнього процесу вищого технічного закладу освіти з формування фрізкультурно-оздоровчої компетентності майбутніх висококваліфікованих срахівців технічних галузей виробництва та охарактеризувати особливості фрізичної активності студентської молоді у позанавчальній діяльності. Методи дослідження. Для вирішення поставлених завдань використовувалися методи дослідження: психолого-педагогічне спостереження з метою з'ясування мотивованості студентської молоді на досягнення успіху в діяльності; анкетування; методи психологічної діагностики з метою оцінки психічного стану осіб, психоемоційної реакції на навантаження; фрізіологічні методи (пульсометрія, тонометрія, функціональні проби) з метою виявлення фрункціонального стану здоров'я; методи рухових тестів з метою визначення індивідуальних рухових здібностей студентів. Результати: обірунтовані та експериментально перевірені педагогічні умови, які забезпечують ефективність формування фрізкультурно-оздоровчої компетентності, ведення здорового способу життя сучасними студентами та орієнтують молодь на якісно активне, позитивно заряджене (здоров'язберігаюче) середовище у вищому технічному навчальному закладі. Відзначено особливості, що вирізняють позанавчальну самостійну роботу від аудиторної, а саме: організація у рамках позанавчального часу студентів $і$ викладачів, тісний межпредметний зв'язок (профресійно-прикладний складник), добровільність участі у спортивних та оздоровчих заходах, гнучкість, різноманітність фрорм позанавчальної роботи, яскраво виражений емочійний та творчий характер (психологічний складник), поповнення і збагачення новими знаннями та практичними навичками. Розділ самостійної позанавчальної роботи забезпечений навчально-методичним матеріалом, організаційно розпланований. Проте ми вважаємо, що він потребує постійного оновлення та удосконалення згідно із сучасними спортивно-оздоровчими програмами, тенденціями в освіті та спорті.
Ключові слова: самоорганізація, середовище, компетентність, студентська молодь, здоров'я, освіта, особистість.

The article is devoted to one of the topical problems in the training of future highly qualified specialists in technical fields of production. In particular, the formation of not only professional competence but also physical and fitness competence among students of higher technical education institutions. In a higher education institution, health education may not be the primary purpose of education, but it should be a central condition of the educational process at the university related to the achievements of the personal achievements of the students' education. The purpose of our research was to analyze the educational process in a higher technical institution of education concerning the formation of physical and health competences of future highly qualified specialists in the technical fields of production and to characterize the peculiarities of physical activity of student youth in extracurricular activities. Research methods. To solve these problems we used the following research methods: psychological and pedagogical observation in order to find out the motivation of student youth to succeed in their activities; questionnaire; methods of psychological diagnostics in order to assess the mental state of persons, psychoemotional response to stress; physiological methods (heart rate, tonometry, functional tests) to identify a functional state of health; methods of motor tests to determine the individual motor abilities of students. Results. The pedagogical conditions, which are substantiated and experimentally tested, which ensure the effective formation of physical and fitness competences, maintain a healthy lifestyle for modern students, and orient the youth to a qualitatively active, positively charged (health-saving) environment in higher technical education.

The peculiarities that distinguish non-academic independentworkfrom the classroomaremarked, namely: organization of students and teachers outside the educational time, close boundaries of subject communication (professional-applied component), voluntary participation in sports and recreation activities, flexibility, variety of forms in outside educational work, pronounced emotional and creative character (psychological component), replenishment and enrichment with new knowledge and practical skills. The section of extracurricular activity is provided with educational and methodical material and organizationally planned. However, we believe that it needs constant updating and improvements in accordance with modern sports and wellness programs, trends in education and sports. Key words: self-organization, environment, competence, student youth, health, education, personality. завідувач касредри фрізичного вихован
Дніпровського державного технічного університету
Постановка проблеми у загальному вигляді. В обстановці зростання кризових явищ у сучасному світі все більшого соціального значення набуває проблема здоров'я учнівської та студент- ської молоді. Особливо актуальною ця проблема стає в наш час, коли Україна переживає складний період становлення незалежної держави і реорормування суспільно-економічних відносин. 
Як свідчить історичний досвід, період інтенсивних реформ завжди негативно відбивається на соціальній сорері. Не винятком $€$ розвиток фрізичної культури та спорту, зокрема серед студентської молоді, яка в умовах розбалансування системи вузівського фрізичного виховання швидко втрачає мотивацію до занять руховою активністю.

Життя і навчання студентів поряд із загальними характеристиками проблем життя сучасної людини - соціально-економічними, духовними, матеріальними, екологічними - має цілу низку особливостей, які притаманні цій категорії молоді. Нове покоління незалежної України виросло в умовах становлення ринкової економіки. Воно суттєво відрізняється від попередніх і має свої цінності та пріоритети, з якими потрібно рахуватися. Сучасні науковці стверджують, що лише сорормована 3 чітко визначеними гуманістичними орієнтаціями молода людина (особистість) за умови фрізичної та психологічної підтримки спроможна протидіяти тискові згаданих негативних чинників і залишатись фрізично і психічно здоровою, врівноваженою, толерантною, здатною контролювати й регулювати власний психічний стан, що абсолютно необхідно для забезпечення становлення майбутнього молодого фрахівця. Все наведене підвищує значимість предмета наших досліджень.

Аналіз останніх досліджень і публікацій. Сучасна система освіти, яка розвивається в умовах статусності відповіді на потреби людини знайти своє місце і можливості до самоорганізації та самореалізації у новому глобальному просторі, своїми орієнтирами починає вбачати не лише знання, уміння й навички, але й загальну фрізичну, психологічну, моральну складові частини людини. Загальна спрямованість на гармонійний розвиток особистості визначає головну мету сучасної освіти як розвиток можливостей особистості, які потрібні їй самій та суспільству, як включення її в соціально-ціннісну діяльність [4, с. 187].

У системі вищої освіти особливого значення набувають принципи виховання, орієнтовані на визнання цінності студента як особистості, його права на вільний розвиток і прояв своїх здібностей. Таким чином, фрормування професійної компетентності майбутніх висококваліфрікованих фрахівців технічного профрілю $\epsilon$ соціально значущою проблемою, а інноваційні процеси, що відбуваються в системі сучасної технічної освіти, виступають механізмом розроблення нових цілей, змісту й технологій формування фрізкультурно-оздоровчої компетентності студентів у технічних навчальних закладах. Аналіз стану висвітлення проблеми свідчить про те, що питанням підготовки майбутніх висококваліфікованих фрахівців технічних напрямів присвячено чималу кількість наукових праць вітчизняних та зарубіжних учених:

\section{- упровадження компетентнісного підходу} в систему освіти висвітлено у роботах Є.Н. Приступи (2012), А.В. Цьося, (2017), І.В. Манжелей (2016) та ін.;

- основи професійної підготовки майбутніх педагогів у вищих навчальних закладах, особливості фрормування їхньої профресійної компетентності розкривають В.П. Андрущенко (2015), О.В. Тимошенко (2018), Н.Н. Завидівська, (2015), Л.В. Волков (2013), Н.В. Москаленко (2014) та ін.;

- руховій активності як складнику здорового способу життя приділяють увагу О.Д. Дубогай (2018), Г.П. Грибан (2016), Л.П. Сущенко (2019) таін.

Обмеження рухової активності студентів знижує захисні механізми організму до несприятливих впливів навколишнього середовища, сприяє розвитку схильності до різних захворювань. Систематичні заняття фрізичними вправами, оздоровчою фрізичною культурою піднімають організм на новий, більш високий рівень розвитку. Інтенсивні спортивні заняття фрормують також пристосувальні перетворення в організмі, які не можуть бути досягнуті у звичайному дозованому використанні засобів фрізичної культури та фрізичній роботі. Важливу роль у залученні студентів до активних занять фрізичними вправами відіграють спортивні традиції сім'ї, школи, 3ВО, система освіти, місце і роль фрізичного виховання та спорту в цій системі, наявність сучасних програм фрізичного виховання та їх виконання викладачами [2, с. 38].

Виділення не вирішених раніше частин загальної проблеми. У літературних джерелах та наукових публікаціях О.В. Тимошенко (2018), Г.П. Грибана (2016), О.Д. Дубогай (2018), О.Г. Гладощука (2017) обґрунтована актуальність побудови освітньо-орієнтованого, здоров'язберігаючого середовища для формування фрізкультурно-оздоровчої компетенції, але структура, зміст і процедура їх побудови та фрізкультурно-оздоровчі, спортивні уподобання, потреби студентської молоді не висвітлюються. Навчально-виховний процес 3 фрізичного виховання потребує оновлення і модернізації, які мають закласти основи фрізкультурнооздоровчої компетентності майбутнього фрахівця в дотриманні здорового способу життя.

Мета проведеного нами дослідження - зробити аналіз освітнього процесу вищого технічного навчального закладу із фрормування фрізкультурнооздоровчої компетентності майбутніх висококваліфікованих фрахівців технічних галузей виробництва та охарактеризувати особливості фрізичної активності студентської молоді у позанавчальній діяльності.

\section{Завдання дослідження:}

1) визначити сутність та значення освітнього здоров'язберігаючого середовища у вищому технічному навчальному закладі; 
2) визначити показники ефективності фрізичної активності студентської молоді у позанавчальній діяльності.

Методи дослідження. Для вирішення поставлених завдань використовувалися методи дослідження: психолого-педагогічне спостереження 3 метою з'ясування мотивованості студентської молоді на досягнення успіху в діяльності; анкетування; методи психологічної діагностики з метою оцінки психічного стану осіб, психоемоційної реакції на навантаження; фрізіологічні методи (пульсометрія, тонометрія, фрункціональні проби) з метою виявлення фрунціонального стану здоров'я; методи рухових тестів з метою визначення індивідуальних рухових здібностей студентів.

Виклад основного матеріалу. На сучасному етапі розвитку технічної освіти Л.Л. Товажнянський визначив низку узагальнених завдань підготовки фрахівців. Серед них, зокрема, - гуманітарна підготовка, самопізнання та саморозвиток професіоналізму, здібностей до самостійного мислення та самоорганізації, готовність до конкурентної боротьби, фрормування духовності, моральності, естетичних ідеалів та смаків, індивідуальної та професійної психофрізичної культури [6, с. 5].

У вищому технічному закладі освіти навчальна дисципліна «Фізичне виховання» за своєю суттю єдина орієнтована дисципліна, що робить прямий, а не опосередкований вплив на здоров'я студентської молоді, орієнтована на фрормування його фрізкультурно-оздоровчих компетенцій у процесі спеціально організованої навчальної та позанавчальної рухової діяльності.

Змістовий і системний аналіз компетентнісного підходу до навчальної діяльності з фрізичного виховання та фрізкультурно-оздоровчих заходів в університетах дали змогу виділити складники фрізкультурно-оздоровчої компетентності майбутніх висококваліфікованих фрахівців. Основоположною ідеєю є те, що фрізкультурно-оздоровчі компетентності студентів забезпечують процес саморозвитку і самовдосконалення, збереження здоров'я, підтримання високого рівня фрізичної підготовленості і працездатності, дотримання здорового способу життя, наявність умінь і навичок залучити до цього інших у процесі професійної діяльності [3, с. 9].

Процес розвитку фрізкультурно-оздоровчої компетентності студентів має три стадії: становлення, активний розвиток і стадія саморозвитку. На стадії становлення відбувається засвоєння студентами необхідних знань щодо режиму рухової активності та оздоровчих технологій, формування відповідних умінь і навичок, формування мотивації до систематичних занять фрізичними вправами, ціннісного та позитивного ставлення до власного здоров'я. На стадії активного розвитку студенти осмислено оперують знаннями і використовують уміння та навички, мають потребу в особистій самореалізації в освітньому середовищі, мають такі розвинені якості, як реолективність, креативність, критичність мислення, мають сорормовані навички саморегуляції навчально-пізнавальної діяльності. Основна мета стадії саморозвитку розвиток самостійності, творчої активності, самоорганізації та самоуправління своєю діяльністю, актуалізація потреби у саморозвитку [1, с. 135].

Провідний науковець І.В. Манжелей стверджує, що в процесі фрормування фрізкультурних компетенцій максимум уваги необхідно приділяти набуттю особового досвіду фрізкультурно-спортивної діяльності через організацію різного роду практик і фрізкультурно-спортивних середовищ. Важливо відзначити, що у разі середовищного підходу акценти в діяльності викладача зміщуються 3 активного впливу на особу студента в сферу побудови елективного (позанавчального) середовища фрізичного виховання, яке насичується різними мікросередовищами, а також сприятливе для активізації внутрішніх механізмів саморозвитку та самовираження студентської молоді [5, с. 274].

Для вирішення поставлених завдань дослідження із фрормування фрізкультурно-оздоровчої компетенції студентської молоді ми запропонували реалізацію педагогічних умов орієнтування студента на якісно активне, позитивне (здоров'язберігаюче) середовище у вищому технічному навчальному закладі. Реалізація педагогічних умов орієнтування студента на культивування спортивного стилю життя, можливості участі у спортивно-масових заходах різного рівня, досягнення спортивних результатів з метою самореалізації і самовираження в Дніпровському державному технічному університеті здійснюється в рамках фрізкультурно-оздоровчої освіти та Концепції виховної роботи університету. Навчальна дисципліна «Фізична культура», на нашу думку, сприяє інформаційному орієнтуванню студента на здоровий спосіб життя за рахунок поєднання двох компонентів - базового (обов'язкового) та елективного (для вирішення окремих завдань). Оптимальне поєднання змісту базового та елективного компонентів програми дисципліни «Фізична культура» ми пов'язуємо з реалізацією, з одного боку, отримання інформації від студентів, а 3 іншого надання більш повної інфрормації студентам у теоретичному і практичному розділах програми щодо орієнтування їх на здоровий спосіб життя.

У Дніпровському державному технічному університеті в 2017 році було розроблено «Положення про організацію студентського рейтингу». Метою впровадження студентського рейтингу $€$ підвищення рівня мотивації студентів до отримання кращих результатів у навчанні, а також до більш результативної участі студентів у науковій, громадській, спортивній роботі та у художній самодіяльності фракультету та університету. Усі резуль- 
тати діяльності студентів оцінюються балами. Максимальна кількість балів, розрахованих за всіма критеріями, становить 100 балів. У тому числі максимальна кількість балів за навчальну роботу становить 90 балів, максимальна сума балів за всі інші види роботи та діяльності - 10 балів.

Дослідження проводилось 32017 року по 2019 рік за програмою НДР «Психолого-педагогічні умови вдосконалення рівня орізичної культури студентської молоді в процесі формування професійної компетентності». У дослідженні брали участь студенти I-III курсів, які за станом здоров'я зараховані до основної та підготовчої медичної груп. Психолого-педагогічне дослідження проводилось у три етапи. На І етапі (перший курс) ставилися такі задачі: отримання первинної інфрормації (анкетування); отримання практичних показників за ЗФП (контрольні нормативи та тести). На II етапі (другий та третій курси): психолого-педагогічне спостереження; надання теоретичного матеріалу; отримання показників із ЗФП та ігрових видів спорту. На III етапі (четвертий курс): отримання підсумкової інорормації про рівень фрізкультурнооздоровчої активності студентської молоді.

На лекціях 3 фрізичного виховання студентів I курсу знайомили 3 тими якостями, які забезпечують успішне опанування професійних навичок.
Надавалася інфрормація про способи діагностики загальної і спеціальної фрізичної підготовленості і методичні матеріали з її визначення та оцінки.

$\mathrm{Ha}$ практичних заняттях проводилося тестування із загальної і спеціальної фрізичної підготовленості, надавалася інформація про зміст і методику складання індивідуальних програм самостійних занять.

У позанавчальний час в університеті як організовані заняття студентам пропонувалися на вибір секції з легкої атлетики, баскетболу, атлетичної гімнастики, волейболу, настільного тенісу та аеробіки.

Усім студентам давалася психологічна настанова на досягнення нормативного рівня розвитку загальнофрізичних і професійно-прикладних фрізичних якостей, які сприяють загальному безпечному рівню фрізичного здоров'я та успішному опануванню професійних навичок, тобто мета у всіх студентів була одна й та сама, а засоби і форми занять фрізичними вправами, руховий режим були різними.

Також на першому етапі було проведено статистичне опитування, в якому взяли участь 350 респондентів, студентів першого курсу - представників різних фракультетів денної форми навчання. Зробивши аналіз отриманих даних (рис. 1), ми встановили, що головним на заняттях з фрізичного виховання $68 \%$ студентів вважають отримання

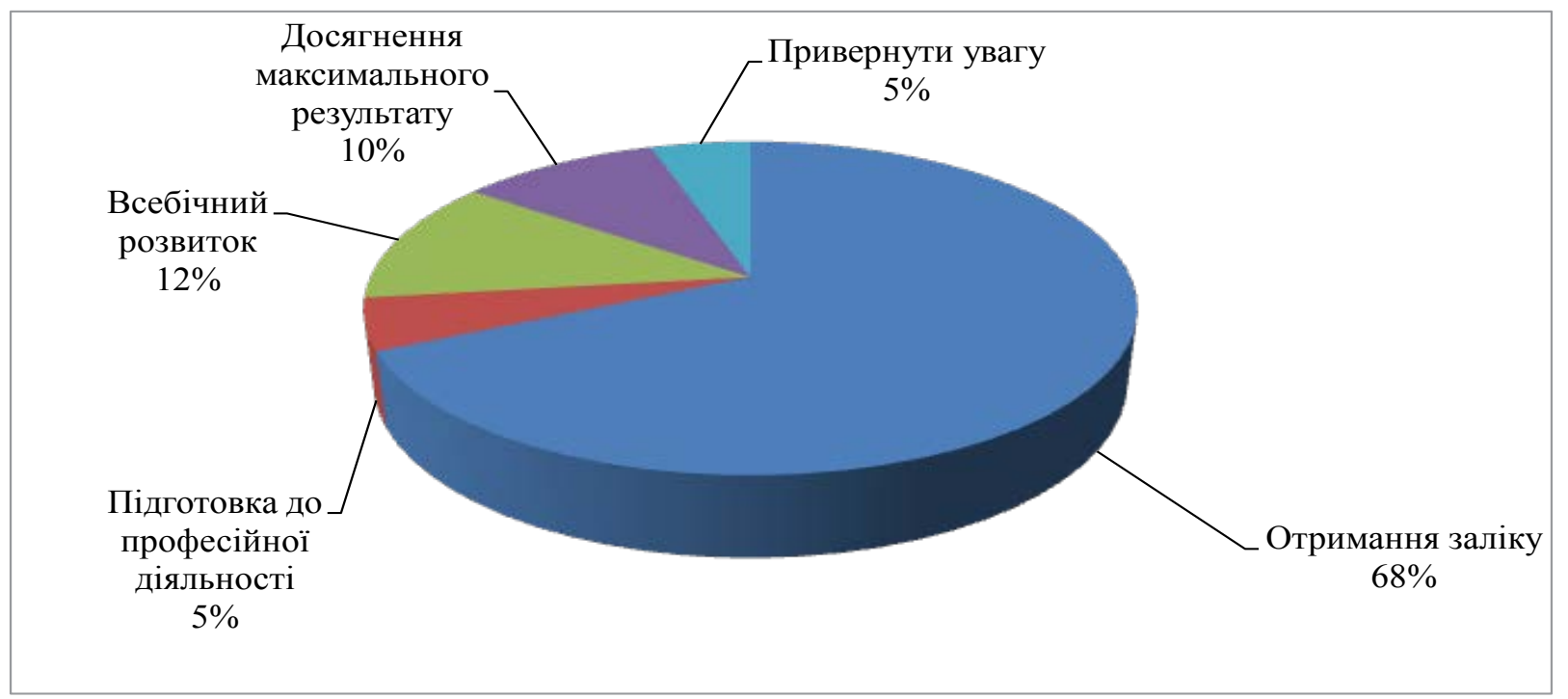

Рис. 1. Результати мотивацій до занять з фрізичного виховання студентів I курсу ДдТУ

Таблиця 1

Позанавчальна діяльність студентської молоді (\%)

\begin{tabular}{|c|l|c|c|c|}
\hline № & \multicolumn{1}{|c|}{ Спортивна та фрізкультурно-оздоровча діяльність } \\
студентів & I курс & II курс & III курс \\
\hline 1 & Спортивні секції університету & 8,4 & 8,2 & 6,0 \\
\hline 2 & Спортивні заходи університету & 12,0 & 12,6 & 10,4 \\
\hline 3 & Фізкультурні та спортивні організації, клуби & 7,6 & 5,2 & 1,4 \\
\hline 4 & Самостійні заняття & 26,8 & 32,4 & 32,0 \\
\hline 5 & Участь у спортивно-масових та оздоровчих заходах & 32,6 & 43,6 & 36,4 \\
\hline
\end{tabular}


заліку з фрізичного виховання як одного з багатьох заліків у програмі навчання, на всебічний розвиток відведено 12\%, досягнення максимального результату - 10\%, привернути увагу до себе та підготовку до профресійної діяльності - відповідно по 5\%.

Для визначення рівня фрізкультурно-оздоровчої активності студентської молоді нами був проведений аналіз участі студентської молоді у спортивномасових та фрізкультурно-оздоровчих заходах університету. Проведення Спартакіади університету серед студентських команд фракультетів вирішує завдання популяризації студентського спорту, укріплення зв'язків між фракультетами, укріплення студентського середовища у рамках реалізації Концепції виховної роботи Дніпровського державного технічного університету.

Відповідно до «Положення про організацію студентського рейтингу» студенти мали можливість протягом усього навчального року заробляти додаткові бали своєю участю у позанавчальній діяльності. Студентам була дана можливість активно долучатись до фрізкультурно-оздоровчого та спортивного життя університету, займаючись у спортивних секціях (легкої атлетики, волейболу, баскетболу, футболу, атлетичної гімнастики, настільного тенісу, спортивної аеробіки, шашок та шахів), беручи активну участь у змаганнях (Спартакіада університету, кубки деканів, легкоатлетичні пробіги), а також у туристичних заходах. Участь у міських та обласних змаганнях та спортивно-оздоровчих заходах студенти мали підтвердити відповідними документами.

Студенти з ослабленим здоров'ям, які з урахуванням діагнозу захворювань і рішенням лікарняної комісії переведені до спеціальної медичної групи, також мають можливість заробити додаткові бали за рахунок участі у спортивних змаганнях та фрізкультурно-оздоровчих заходах як помічники судді або волонтерської діяльності. Також студенти спеціальної медичної групи беруть активну участь у конкурсі соціального плаката «Здоровий спосіб життя».

Проведене дослідження підтверджує, що на кожному з трьох етапів найбільшого розвитку набувають окремі компоненти фрізкультурнооздоровчої компетентності. На підготовчому етапі такими компонентами є мотиваційний та емоційно-вольовий, на другому етапі (базовому) когнітивний та діяльнісний, на третьому етапі відбувається інтегрування всіх компонентів на базі рефлексивної діяльності.

Висновки. Обґрунтовані та експериментально перевірені педагогічні умови, які забезпечують есрективність орормування фрізкультурно-оздоровчої компетентності, ведення здорового спо- собу життя сучасними студентами та орієнтують молодь на якісно активне, позитивно заряджене (здоров'язберігаюче) середовище у вищому технічному навчальному закладі.

Доведена ефективність фрормування фрізкультурно-оздоровчої компетентності студентів у здоров'язберігаючому середовищі вищого технічного закладу освіти, що проявилося у підвищенні показників їх активності у позанавчальній діяльності, в підвищенні показників мотивації та потреб до рухової активності, в достовірному підвищенні фрізкультурної обізнаності і позитивній динаміці їхнього фрізичного стану та фрізичній підготовленості. Відзначено особливості, що вирізняють позанавчальну самостійну роботу від аудиторної, а саме: організація у рамках позанавчального часу студентів і викладачів, тісний межпредметний зв'язок (професійно-прикладний складник), добровільність участі у спортивних та оздоровчих заходах, гнучкість, різноманітність форм позанавчальної роботи, яскраво виражений емоційний та творчий характер (психологічний складник), поповнення і збагачення новими знаннями та практичними навичками.

\section{БІБЛІОГРАФІЧНИЙ СПИСОК:}

1. Гладощук О.Г. Формування фрізкультурнооздоровчої компетентності студентів вищих технічних навчальних закладів. Науковий часопис Національного педагогічного університету імені М.П. Драгоманова. Серія № 15. «Науково-педагогічні проблеми фрізичної культури. Фізична культура i спорт» : зб. наукових праць / За ред. О.В. Тимошенка. Київ : Вид-во НПУ імені М.П.Драгоманова, 2017. Випуск ЗК(84)17. С. 132-135.

2. Грибан Г.П. Життєдіяльність та рухова активність студентів : монографія. Житомир : Вид-во Рута, 2009. 594 c.

3. Грибан Г. Технологія фрормування фрізкультурно-оздоровчих компетентностей у студентів засобами особистісно орієнтованого підходу до фрізичного виховання. Фізична культура, спорт та здоров'я нації : збірник наукових праць. Вип. 2. Житомир : Вид-во ФОП Євенок О.О., 2016. С. 18-25.

4. Гущина Т.Н. Педагогическая сущность феномена «образовательная среда»: по материалам исследования. Общество. Среда. Развитие (Terra Humana). 2011. № 4. C. 187-190.

5. Манжелей И.В. Формирование фризкультурной компетентности бакалавров / И.В. Манжелей, C.Н. Чернякова. Вестник Тюменского государственного университета. Гуманитарные исследования. Humanitates. 2016. Том 2, № 1. С. 270-282.

6. Товажнянський Л.Л. Нова парадигма інженерної освіти і підготовка національної гуманітарно-технічної еліти. Теорія і практика управління соціальними системами. 2002. № 2. С. 3-9. 